\title{
Copyright Corner
}

Introduction

"...intellectual property protection is still a giant shaking finger in the face of the full freedom to explore and exploit the myriad opportunities."

\section{A Balancing Act, Part I: Exclusive Rights by Lynne Crandall, University of Michigan}

The fabric of copyright law is being stretched, tested and defined by many forces, both in the United States and around the world. The Internet, with its ease of access, uploading, and downloading, fosters a unique form of creativity and inquiry. Anyone who has a computer, a connection, an idea and a bit of curiosity can do almost anything-can't they?

The recent Sixth Circuit Court of Appeals ruling for the Michigan Document Service ${ }^{1}$ upheld fair use coursepack duplication for regular instructional purposes, even if the duplication is performed by a for-profit entity. Distance education transforms classroom boundaries and forces us to reconsider the legal parameters in which media enhancements may be used. The Multimedia Fair Use Guidelines ${ }^{2}$ outline what will probably be "safe" territory for educators and students who want to assemble digital text, images and sounds to create multimedia lessons, comparisons and compositions. While the Guidelines represent a great step in the right direction, they are not law, and not everyone has agreed to them. Discussions of ownership, remedies, transitory copies, synchronization rights, derivative works, personal scholarship, academic freedom and civil obedience can make the head swim!

So what is all the fuss about? There is a body of law that defines what is and is not protected under copyright, isn't there? Yes, but unfortunately the law is intentionally fuzzydrafted during a time when information was still primarily transmitted by hand via pencil and paper, and audiovisuals 
were often cumbersome and complicated for individuals to use. The advent of home recording equipment, the digital revolution and a networked world raised the possibilities for information creation and relay to a new level. The law has undergone a number of revisions in an attempt to keep up with the changing technological freedoms. But intellectual property protection is still a giant shaking finger in the face of the full freedom to explore and exploit the myriad opportunities. What is a conscientious educator to do? Follow the letter of the law? Test the limits and take personal and institutional risks? Questions are being asked. Does the U.S. copyright law need to be re-written? Is its corpus sound, and its interpretation in need of reexamination? Does the structure, ability and need of society warrant a changed perspective?

\section{A Constitutional} Foundation

\section{Weighing in on the limited exclusive rights side of the scale...}

The United States Constitution lays a foundation for Congress to create intellectual property laws that balance individual property rights with the needs of the public to use this same property. Congress gave authors and inventors limited, exclusive right to their respective writings and discoveries to encourage progress in the arts and sciences. We are all familiar with our system of credit and reward for material creation. Content proprietors, including individual creators and the publishing and distributing industries, do have a right to exert a measure of control over their property. However, it is important to reiterate: a balance is supposed to be achieved. The counterweight to exclusive rights is the need of the public to use copyrighted works to further knowledge and foster creation of new works.

Copyright protects an author's original, tangible, form of expression. It doesn't extend to any ideas, system or factual information that is conveyed in a copyrighted work, and it doesn't extend to any pre-existing material that the author has incorporated into a work (17 U.S.C. 102(b), 103).

In this first of two columns, I will examine the content proprietors' rights. Below is a summary of the seven rights related to copyright law and some samples that indicate what actions these rights might cover. If you are wondering, "Seven rights? I thought there were five!" I haven't lost my math skills! I am including (as attorney Terry Carroll does in his Copyright $\mathrm{FAQ}^{3}$ ) the two moral rights found in the Berne Convention. While these rights are not found in the U.S. Copyright Code ${ }^{4}$, they are found in other bodies of federal and state law. Items in chevrons are meant to indicate generic terms. 
Title 17, United States Copyright Code
The "bundle" of rights found in Title 17 of the United States Copyright Code includes:

1) Reproductive right-the right to reproduce the work in copies. Some examples of reproduction are to

- digitize segments

- press a master laser disc or $C D$

- transfer a program from 3/4" U-Matic format to $1 / 2$ " VHS format

- convert a PAL videocassette to the NTSC standard

- tape a program off satellite, cable or broadcast TV

In each of these instances, a new, perceivable, copy of the work is created.

2) Adaptative right-the right to produce derivative works based on a copyrighted work. A work based on one or more pre-existing works, such as a translation, musical arrangement, dramatization, art reproduction, abridgment, condensation or any other form in which a work may be recast, transformed or adapted. A work consisting of editorial revisions, annotations, elaborations or other modifications, which as a whole represent an original work of authorship, is a derivative work. Examples include to

- incorporate <digitized media, regardless of original media type $>$ into a computer-based multimedia application

- edit the program into a short segment (even if original context maintained)

- compile the <program(s)> into short, content-based segments (even if original context maintained)

- synchronize music and narrative to a series of images to create a presentation <program>

3) Distribution right - the right to distribute copies of the work. To

- test the <resulting multimedia application $>$ at $<$ institution>, <location> during <duration>

- make copies of <resulting multimedia application> available for use in the classroom and at multiple <university> computer sites in a networked environment on servers from which copying is prohibited

- distribute the resulting materials as part of an audiovideo package with the entitled $<$ Textbook $X>$.

- if distribution of the material is not authorized, make available with $<$ Textbook $X>$ our segment references and accompanying pedagogical materials 
The Moral Rights from the Berne Convention

Suggested Reading
4) Performance right-the right to perform the copyrighted work publicly.

5) Display right-the right to display the copyrighted work publicly. Although performance and display rights do not mean precisely the same thing, they are quite similar. Each involves enabling the work to be perceived by the public. It is important to keep in mind that the public includes educational settings. When part of regular, non-profit instruction, the classroom is an exempted public setting(17 U.S.C. 102(b)). This includes:

- use of the programs for course related purposes at $<$ institution>

- making the programs available for group or individual viewing, for enrichment and general educational purposes to the <university> community

- demonstrating the <resulting computer application $>$ at professional meetings and conferences when presenting a synopsis of the project

6) Attribution right-the right of the author to claim authorship of the work and to prevent the use of his or her name as the author of a work he or she did not create; in the US, this law is known as unfair competition. It governs the taking of someone else's work without obtaining their permission or giving credit to them and is called misappropriation. Thus:

- give full credit in the <resulting multimedia application and in any corresponding print materials>

7) Integrity right-the right of an author to prevent the use of his or her name as the author of a distorted version of the work, to prevent intentional distortion of the work, and to prevent destruction of the work. This is recognized at the state level and protects visual artists' rights against alteration and distortion of their works. An example of this is to

- "morph" the image from its original form to <new form>

In my next column, "A Balancing Act, Part II," I will look at the other side of the copyright balance: the public's need to use copyrighted works. In the meantime, may I suggest a couple of books presenting interesting perspectives on copyright? 
L. Ray Patterson and Stanley W. Lindberg, The Nature of Copyright: A Law of User's Rights, University of Georgia Press, 1991. This 274-page book examines the historical basis of copyright and applies these foundations and principles to the interpretation of the US Copyright Code today. It is a pleasantly comprehensible analysis.

Kenneth D. Crews, Copyright, Fair Use, and the Challenge for Universities: Promoting the Progress of Higher Education, The University of Chicago Press, 1993. This 247-page book looks at copyright law and fair use applications in the context of the policies, guidelines and practices of educational institutions. Extensive institutional references provide an attachment to reality often missing in copyright books.

Disclaimer

It is important to note that I am not an attorney, and have no formal legal training. This column is my best attempt to share interesting information with IALL Journal readers. It reflects my personal experiences and observations, and not the position of my institution. Personal opinions and institutional cultures vary widely. If you have questions about observances of intellectual property law, I strongly urge you to seek the advice of your institution's legal counsel!

Notes 'http://www.law.emory.edu/6circuit/feb96/ 96a0046p.06.html

${ }^{2}$ http:/ / www-act.ucsd.edu/webad/ fairuse.html

${ }^{3}$ Portions excerpted, with permission, from the Copyright FAQby Terry Carroll, gopher://gopher.cni.org:70/00/cniftp/ forums/cni-copyright/other/faq.part2

${ }^{4}$ http:/ / www.law.cornell.edu/usc/17/overview.html\#101

Lyne Crandall is a Media Consultant at the Language Resource Center, University of Michigan-Ann Arbor. 


\section{NEW! ETI-P224 DUAS CHANWEL}

features microprocessor operation to 手AST 爯ORWARD LANGUAGE LEARNING

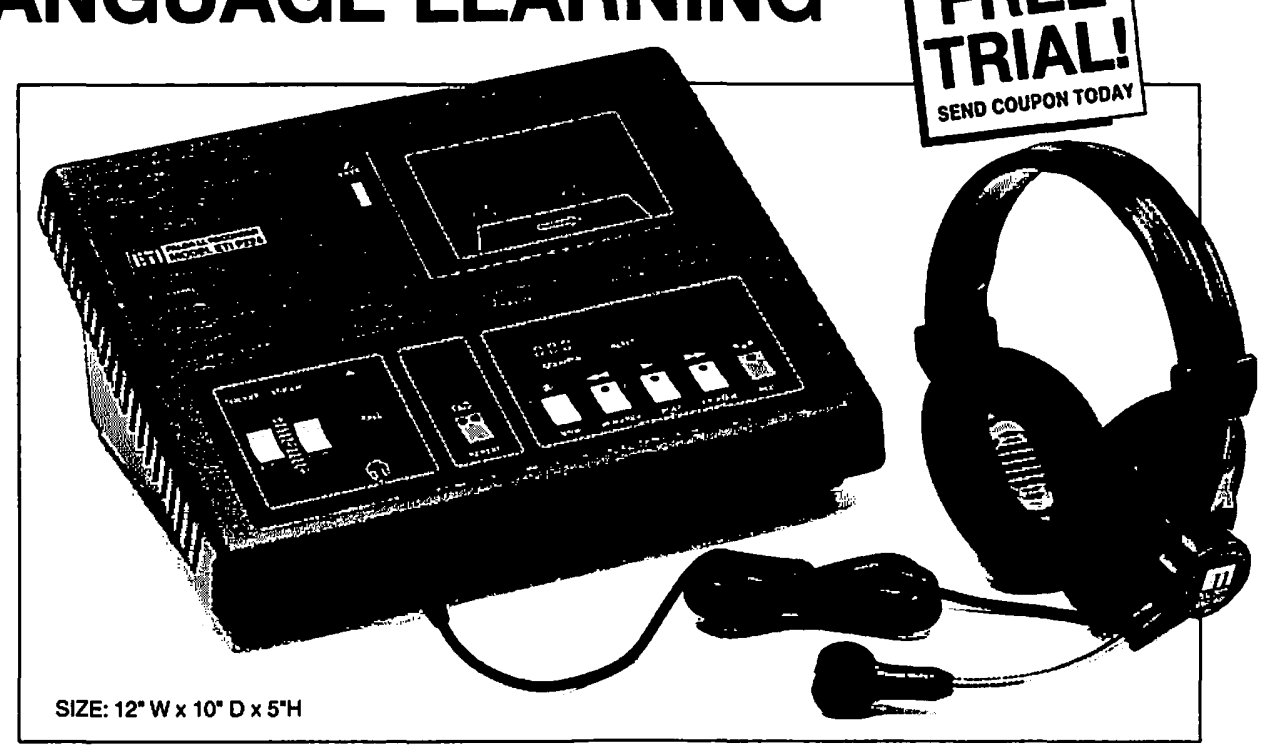

\section{TECHNICAL SPECIFICATIONS}

- TRACKS -

$1 / 4$ track, dual channel

$\square$ SPEED -

$1 \%$ inches per second

COUNTER -

3 digit LED display

- RECORDING -

Automatic Level Control (ALC)

MOTORS -

2 Independent Regulated Motors
FREQUENCY RESPONSE 40 to $12000 \mathrm{~Hz}$

$\square$ POWER REQUIREMENTS Completely portable. Uses ordinary power (110 Volts $A C$ )

口 MICROPHONE INPUT 0.15-1.5mV (3 kOhms)

HEADPHONE OUTPUT . $3 \mathrm{~V}$ at $200 \mathrm{Ohms}$

- OPERATING TEMPERATURE $40^{\circ} \mathrm{F}$ to $125^{\circ} \mathrm{F}$

\section{FEATURES}

DUAL CHANNEL FUNCTION

SELECTIVE REPEAT

DUAL VOLUME CONTROLS

CUE and REVIEW

CREATES MASTER TAPES

CLASSROOM LOUD SPEAKER

LIGHTED SWITCHES

ALL ELECTRONIC SWITCHING

PROTECTED MASTER TRACK

COMPLETE WITH MATCHING

HEADSET

and more!

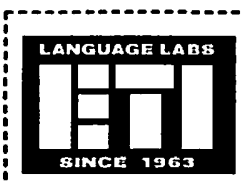

EOUCATIONAL TECHMOLOQY INC.

2224 Hewlett Ave., Merrick, NY 11566-3692

Phone: (516) 623-3200

(800) 942-2136

Fax: (516) 378-2672

E mail: eti $2000 @ \mathrm{aol} \cdot \mathrm{com}$

\section{MAIL THIS FORM TODAY FOR DETAILS AND PRICES}

NAME

SCHOOL

STREET

CITY

STATE ZIP
Please send prices and specifications for ETI.P224 $\square$ Please send details for 10 day FREE trial.

$\square$ Please send Language Laboratory information 